Value Jurnal IImiah Akuntansi Keuangan dan Bisnis

Vol. 1 No. 1 Bulan April - September 2020

\title{
ANALISIS LIKUIDITAS PT. ANGKASA PURA II (PERSERO) KUALANAMU INTERNATIONAL AIRPORT
}

\author{
Fariza Habibi, SE, MM dan Alamin Hasibuan \\ Fakultas Ekonomi Universitas Tjut Nyak Dhien, Program Studi Manajemen \\ Email: Fariza.Habibie88@gmail.com
}

\begin{abstract}
This study aims to determine the ability of PT. Angkasa Pura II (Persero) Kualanamu International Airport in meeting its short-term obligations in 2017 and 2018. Data analysis techniques are quantitative methods. This is done to compare the company's ability to meet its short-term obligations in 2017 with 2018. Based on the results of the study, it is known that the level of liquidity ratios in this company generally meets the established ratio standards. Although there is a decrease, but the decline is not too low and is still in accordance with the ratio and industry standards.
\end{abstract}

Keywords: Ratio Analysis, Liquidity Ratio

Abstrak

Penelitian ini bertujuan untuk mengetahui tingkat kemampuan PT. Angkasa Pura II (Persero) Kualanamu International Airport dalam memenuhi kewajiban jangka pendeknya tahun 2017 dan tahun 2018. Teknik analisis data yaitu metode kuantitatif. Hal ini dilakukan untuk membandingkan kemampuan perusahaan dalam memenuhi kewajiban jangka pendeknya Tahun 2017 dengan Tahun 2018. Berdasarkan hasil penelitian, diketahui bahwa Tingkat rasio likuiditas pada Perusahaan ini Secara umum telah memenuhi standar rasio yang ditetapkan. Meskipun terdapat penurunan, namun penurunan tersebut tidak terlalu rendah dan masih dalam keadaan sesuai dengan standar rasio maupun standar industri.

\section{Kata kunci: Analisis Rasio, Rasio Likuiditas}

\section{Pendahuluan}

Dalam menghadapi krisis finansial yang terjadi sekarang ini, sebuah perusahaan ataupun lembaga usaha baik milik pemerintah maupun swasta dituntut untuk lebih memaksimalkan kinerjanya dalam berbagai hal. Dalam melakukan hal tersebut di dalam sebuah perusahaan atau lembaga usaha diperlukan manajemen yang baik, yang bisa mengelola semuanya dengan maksimal.

Setiap perusahaan yang berorientasi dalam mencari keuntungan membutuhkan laporan keuangan. Laporan keuangan ini menggambarkan kondisi keuangan perusahaan pada periode tertentu. Untuk mendapatkan gambaran mengenai perkembangan keuangan perusahaan, maka perlu dilakukan analisis atas laporan keuangan tersebut yang telah dikonfirmasi 
Value Jurnal IImiah Akuntansi Keuangan dan Bisnis

Vol. 1 No. 1 Bulan April - September 2020

di dalam laporan keuangan yang meliputi: Neraca, Laporan Laba Rugi, Laporan Perubahan Ekuitas, Laporan Arus Kas dan Catatan atas Laporan Keuangan.

Hasil dari analisis laporan keuangan ini dapat dipergunakan oleh pihak-pihak yang berkepentingan dengan perusahaan tersebut, baik bagi pihak intern perusahaan maupun pihak ekstern perusahaan. Bagi pihak intern khususnya manajer, hasil dari analisis ini merupakan alat untuk mempertanggung jawabkan kepada pemilik atau pemegang saham perusahaan tersebut atas kepercayaan yang telah diberikan untuk mengelola perusahaan. Sedangkan bagi pihak ekstern perusahaan yang terdiri dari investor, kreditor dan pemerintah hal ini berguna untuk mengetahui kondisi dan kinerja keuangan perusahaan. Analisis dan interpretasi laporan keuangan dilakukan antara lain dengan menggunakan analisis rasio yang bertujuan menentukan tingkat likuiditas, solvabilitas, aktivitas usaha dari perusahaan dan profitabilitas perusahaan.

Analisis rasio likuiditas sebagai salah satu analisis rasio keuangan merupakan analisis pengukuran kemampuan perusahaan dalam memenuhi kewajiban financial jangka pendek pada saaat jatuh tempo. Rasio-rasio likuiditas perusahaan terdiri dari current ratio dan quick ratio. Anlisis dapat dilakukan dengan membandingkan rasio sekarang dengan rasio tahun-tahun sebelumnya. Sehingga dapat diketahui perubahan-perubahan ratio tersebut dari tahun ketahun. Hasil analisis rasio merupakan bahan pertimbangan bagi perusahaan dalam pengambilan keputusan dan hasil ini juga dibutuhkan oleh perusahaan untuk mencegah kegagalan dalam memperoleh dana dan pengalokasiannya.

\section{Tinjauan Pustaka}

\subsection{Laporan Keuangan Perusahaan}

\section{a. Pengertian dan Tujuan Penyusunan}

\section{Laporan Keuangan}

Dalam upaya untuk membuat keputusan yang rasional, pihak ekstern perusahaan maupun pihak intern perusahaan seharusnya menggunakan suatu alat yang mampu menganalisis laporan keuangan yang disajikan oleh perusahaan yang bersangkutan. Di bawah ini merupakan pengertian laporan keuangan dari beberapa ahli.

Menurut Hanafi dan Halim (2009:63): "Laporan keuangan adalah laporan yang diharapkan bisa memberi informasi mengenai perusahaan, dan digabungkan dengan informasi yang lain, seperti industri, kondisi ekonomi, bisa 
Value Jurnal IImiah Akuntansi Keuangan dan Bisnis

Vol. 1 No. 1 Bulan April - September 2020

memberikan gambaran yang lebih baik mengenai prospek dan resiko perusahaan".

Dalam Standar Akuntansi Keuangan (IAI, 2008:47): “Laporan Keuangan adalah laporan yang menggambarkan dampak keuangan dari transaksi dan peristiwa lain yang diklasifikasikan dalam beberapa kelompok besar menurut karakteristik ekonominya".

Berdasarkan beberapa pengertian di atas, dapat disimpulkan bahwa Laporan keuangan adalah:

a. Merupakan produk akuntansi yang penting dan dapat digunakan untuk membuat keputusan-keputusan ekonomi bagi pihak internal maupun pihak eksternal perusahaan.

b. Merupakan potret perusahaan, yaitu dapat menggambarkan kinerja keuangan maupun kinerja manajemen perusahaan, apakah dalam kondisi yang baik atau tidak.

c. Merupakan rangkaian aktivitas ekonomi perusahaan yang diklasifikasikan, pada periode tertentu.

d. Merupakan ringkasan dari suatu proses transaksi-transaksi keuangan yang terjadi selama periode yang bersangkutan.

Tujuan laporan keuangan adalah memberikan informasi mengenai posisi keuangan, kinerja keuangan, dan arus kas entitas yang bermanfaat bagi sebagian besar kalangan pengguna laporan dalam pembuatan keputusan ekonomi. Laporan keuangan juga menunjukkan hasil pertanggungjawaban manajemen atas penggunaan sumber daya yang dipercayakan kepada mereka. (PSAK, 2009)

\section{b. Elemen Laporan Keuangan}

Laporan keuangan yang lengkap biasanya meliputi:

a. Neraca.

b. Laporan Rugi Laba.

c. Laporan Perubahan Ekuitas, Laporan Perubahan Posisi Keuangan yang dapat disajikan berupa Laporan Arus Kas atau Laporan Arus Dana.

d. Catatan dan laporan lain serta materi penjelasan yang merupakan bagian integral dari laporan keuangan.

\section{Neraca}

Harahap (2009:107) mengemukakan bahwa: "Laporan neraca atau daftar neraca disebut juga laporan posisi keuangan perusahaan. Laporan ini menggambarkan posisi aktiva, kewajiban, dan modal pada saat tertentu. Laporan ini disusun setiap saat dan merupakan opname situasi keuangan pada saat itu”. 
Value Jurnal IImiah Akuntansi Keuangan dan Bisnis

Vol. 1 No. 1 Bulan April - September 2020

Unsur-unsur yang terdapat dalam neraca adalah sebagai berikut:

dan digunakan dalam kegiatan perusahaan.

\section{a. Aktiva / Harta}

5) Aktiva lain adalah aktiva yang dimiliki

Aktiva adalah segala sesuatu yang mempunyai nilai uang yang dimiliki perusahaan yang dapat dimanfaatkan untuk menjalankan operasinya dalam usaha untuk memperoleh pendapatan.

1) Aktiva lancar adalah aktiva yang meliputi uang kas atau setara kas yang penggunaannya tidak dibatasi dan saldo simpanan di bank serta aktivaaktiva lainnya yang akan dapat direalisasi, bisa dicairkan menjadi uang atau yang dipakai dalam operasi perusahaan dalam jangka pendek.

2) Investasi jangka panjang adalah penyertaan pada perusahaan lain dalam bentuk saham atau obligasi dengan tujuan untuk memperoleh pendapatan yang tetap secara terus-menerus.

3) Aktiva tetap berwujud adalah aktiva yang mempunyai bentuk fisik dan dimiliki tidak untuk dijual kembali dalam kegiatan normal perusahaan dan mempunyai masa manfaat lebih dari satu tahun.

4) Aktiva tetap tidak berwujud adalah kekayaan perusahaan yang secara fisik tidak nampak tetapi mempunyai nilai

perusahaan yang tidak dapat dimasukkan sebagai kelompok aktiva sebelumnya.

\section{b. Hutang}

Menurut Munawir (2007:18) "Hutang adalah semua kewajiban keuangan perusahaan kepada pihak lain".

Utang dibedakan menjadi 2 yaitu:

1) Utang lancar adalah kewajiban keuangan perusahaan yang harus dilunasi dalam jangka pendek (satu tahun sejak tanggal neraca).

2) Utang jangka panjang adalah kewajiban keuangan perusahaan yang harus dilunasi dalam jangka lebih dari satu tahun sejak tanggal neraca.

\section{c. Modal}

Menurut Munawir "modal adalah hak atau bagian yang dimiliki oleh pemilik perusahaan yang ditunjukkan dalam pos modal (modal saham), laba ditahan. Atau kelebihan nilai aktiva yang dimiliki oleh perusahaan terhadap seluruh hutanghutangnya".

Menurut Kasmir (2008:35) dalam praktiknya terdapat beberapa bentuk neraca yaitu : 
Value Jurnal IImiah Akuntansi Keuangan dan Bisnis

Vol. 1 No. 1 Bulan April - September 2020

1) Bentuk Skontro (Account form)

Merupakan neraca yang bentuknya seperti huruf "T". Oleh karena itu sering juga disebut $\mathrm{T}$ Form. Dalam bentuk ini neraca dibagi kedalam dua posisi, yaitu disebelah kiri berisi aktiva dan sebelah kanan yang berisi kewajiban dan modal. Contoh NeracaBentuk Skontro (Account form) :

PT. XXX

NERACA

30 DESEMBER 2011.

\begin{tabular}{|c|c|c|c|}
\hline AKTIVA & & PASIVA & \\
\hline $\begin{array}{l}\text { Aktiva } \\
\text { Lancar }\end{array}$ & & $\begin{array}{l}\text { Utang } \\
\text { Lancar }\end{array}$ & \\
\hline -Kas & $\mathrm{xxx}$ & $\begin{array}{l}\text {-Utang } \\
\text { Wesel }\end{array}$ & $\mathrm{xxx}$ \\
\hline -Bank & $\mathrm{xxx}$ & $\begin{array}{l}\text {-Utang } \\
\text { Dagang }\end{array}$ & $\mathrm{xxx}$ \\
\hline $\begin{array}{l}\text {-Surat-surat } \\
\text { berharga }\end{array}$ & $\mathrm{xxx}$ & $\begin{array}{l}\text {-Utang Bank } \\
1 \text { Tahun }\end{array}$ & $\mathrm{Xxx}$ \\
\hline -Piutang & $\mathrm{xxx}$ & -Utang Pajak & $\mathrm{Xxx}$ \\
\hline -Sediaan & $\mathrm{xxx}$ & $\begin{array}{l}\text {-Dan Lain- } \\
\text { lain }\end{array}$ & $\mathrm{Xxx}$ \\
\hline & 000 & & 000 \\
\hline AktivaTetap & & $\begin{array}{l}\text { Utang } \\
\text { Jangka } \\
\text { Panjang }\end{array}$ & \\
\hline -Tanah & $\mathrm{XxX}$ & -Obligasi & $\mathrm{Xxx}$ \\
\hline -Bangunan & $\mathrm{xxx}$ & -Hipotek & $\mathrm{Xxx}$ \\
\hline $\begin{array}{l}\text {-Mesin- } \\
\text { mesin }\end{array}$ & $\mathrm{xxx}$ & $\begin{array}{l}\text {-Utang Bank } \\
3 \text { tahun }\end{array}$ & $\mathrm{Xxx}$ \\
\hline \multirow[t]{2}{*}{-Peralatan } & Xxx & & \\
\hline & 000 & & 000 \\
\hline $\begin{array}{l}\text { Aktiva } \\
\text { Lainnya }\end{array}$ & & Ekuitas & \\
\hline \multirow{3}{*}{$\begin{array}{l}\text { Gedung } \\
\text { dalam proses }\end{array}$} & $\mathrm{xxx}$ & -Modal Setor & $\mathrm{xxx}$ \\
\hline & & $\begin{array}{l}\text {-Laba } \\
\text { Ditahan }\end{array}$ & $\mathrm{Xxx}$ \\
\hline & 000 & & 000 \\
\hline Total Aktiva & 000 & Total Pasiva & 000 \\
\hline
\end{tabular}

\section{2) Bentuk Vertikal (Report form)}

Dalam bentuk laporan isi neraca disusun mulai dari atas terus kebawah, yaitu mulai dari aktiva lancar seperti kas, bank, efek, ialah komponen aktiva tetap,komponen aktiva lainnya, komponen kewajiban lancar, komponen utang jangka panjang dan terakhir adalah komponen modal (ekuitas). Contoh neraca bentuk stafel (Report Form) :

PT. XXX
NERACA

30 DESEMBER 2011

\begin{tabular}{|l|c|}
\hline Aktiva Lancar & $\mathrm{Xxx}$ \\
\hline -Kas & $\mathrm{Xxx}$ \\
\hline -Bank & $\mathrm{Xxx}$ \\
\hline -Surat-surat berharga & $\mathrm{Xxx}$ \\
\hline -Piutang & $\mathrm{Xxx}$ \\
\hline -Sediaan & 000 \\
\hline Total Aktiva Lancar & \\
\hline & \\
\hline AktivaTetap & $\mathrm{Xxx}$ \\
\hline -Tanah & $\mathrm{Xxx}$ \\
\hline -Bangunan & $\mathrm{Xxx}$ \\
\hline -Mesin-mesin & $\mathrm{Xxx}$ \\
\hline -Peralatan & 000 \\
\hline Total Aktiva Tetap & \\
\hline & \\
\hline Aktiva Lainnya & 000 \\
\hline Gedung dalam proses & \\
\hline Total Aktiva Lainnya & \\
\hline & \\
\hline Total Aktiva & \\
\hline & \\
\hline
\end{tabular}


Value Jurnal IImiah Akuntansi Keuangan dan Bisnis

Vol. 1 No. 1 Bulan April - September 2020

\begin{tabular}{|l|c|}
\hline Utang Lancar & \\
\hline -Utang Wesel & $\mathrm{Xxx}$ \\
\hline -Utang Dagang & $\mathrm{Xxx}$ \\
\hline -Utang Bank 1 Tahun & $\mathrm{Xxx}$ \\
\hline -Utang Pajak & $\mathrm{Xxx}$ \\
\hline -Dan Lain-lain & $\mathrm{Xxx}$ \\
\hline Total Utang Lancar & 000 \\
\hline & \\
\hline Utang Jangka Panjang & $\mathrm{Xxx}$ \\
\hline -Obligasi & $\mathrm{Xxx}$ \\
\hline -Hipotek & $\mathrm{Xxx}$ \\
\hline -Utang Bank 3 tahun & 000 \\
\hline $\begin{array}{l}\text { Total Utang Jangka } \\
\text { Panjang }\end{array}$ & \\
\hline & $\mathrm{Xxx}$ \\
\hline Ekuitas & 000 \\
\hline -Modal Setor & \\
\hline -Laba Ditahan & \\
\hline Total Ekuitas & \\
\hline & \\
\hline Total Pasiva & \\
\hline
\end{tabular}

\section{Laporan Laba Rugi}

Laporan laba rugi (income statement) merupakan laporan mengenai pendapatan dan beban-beban suatu perusahaan selama periode tertentu. Laporan laba rugi juga merupakan tujuan utama untuk mengukur tingkat keuntungan dari perusahaan dalam suatu periode tertentu. Hasil akhir dari suatu laporan laba rugi adalah keuntungan bersih atau kerugian.
Kemudian bila perusahaan tidak membagi deviden, maka seluruh hasil akhir tersebut menjadi laba ditahan. Tetapi bila perusahaan membagi deviden, maka hasil akhir tersebut terlebih dahulu dikurangi dengan deviden untuk memperoleh nilai laba ditahan.

Ada dua pendekatan sebagai dasar dalam menggolongkan serta mengikhtisarkan transaksi-transaksi yang terjadi dalam perusahaan, kedua pendekatan itu adalah:

1) Dasar Tunai (Cash Basis): Suatu sistem yang mengakui penghasilan pada saat uang tunai diterima dan mengakui beban pada saat mengeluarkan uang tunai. Cocok untuk perusahaan dengan skala kecil, karena mentode ini kurang tepat untuk mengakui laba atau rugi laba pada periode tertentu.

2) Dasar Waktu ( Akrual Basis ) : Sistem yang mengakui pendapatan pada saat terjadinya transaksi, walaupun sudah atau belum menerima uang tunai dan mengakui beban pada saat terjadinya transaksi walaupun sudah atau belum mengeluarkan uang tunai. Tepat untuk perusahaan yang melakukan transaksi secara kredit, karena laporan laba rugi akan mencerminkan kondisi yang benar selama satu periode tertentu. 
Value Jurnal IImiah Akuntansi Keuangan dan Bisnis

Vol. 1 No. 1 Bulan April - September 2020

Dalam laporan laba rugi, terdapat tiga rekening (akun) yang perlu dipahami yaitu:

1) Pendapatan, adalah penghasilan yang timbul dari pelaksanaan aktivitas perusahaan yang biasa (reguler) contoh : penjualan, penghasilan jasa (fee), bunga, deviden, royalti dan sewa.

2) Beban, adalah pengorbanan yang timbul dalam pelaksanaan aktivitas yang biasa (reguler), seperti beban pokok penjualan, beban gaji, beban sewa, beban penyusutan aset tetap, beban asuransi, beban pajak, beban kerugian piutang.

3) Laba terjadi bila pendapatan lebih besar dari beban-beban yang terjadi, sebaliknya Rugi terjadi bila pendapatan lebih kecil dari beban yang terjadi.

Menurut Kasmir (2012; 49) bentuk dari laporan laba rugi yang bisa digunakan adalah sebagai berikut"

1) Bentuk Tunggal atau single step yaitu dengan menggabungkan semua penghasilan, baik pokok (operasional) maupun diluar pokok (non operasional) dijadikan satu, kemudian jumlah biaya pokok dan diluar pokok juga dijadikan satu. Dengan demikian, faktor pengurangnya adalah jumlah seluruh penghasilan dengan jumlah seluruh biaya. Artinya dalam bentuk ini laporan laba rugi disusun tanpa membedakan pendapatan dan biaya usaha dan diluar usaha lain.

Contoh Bentuk Laporan Laba Rugi Single

Step :
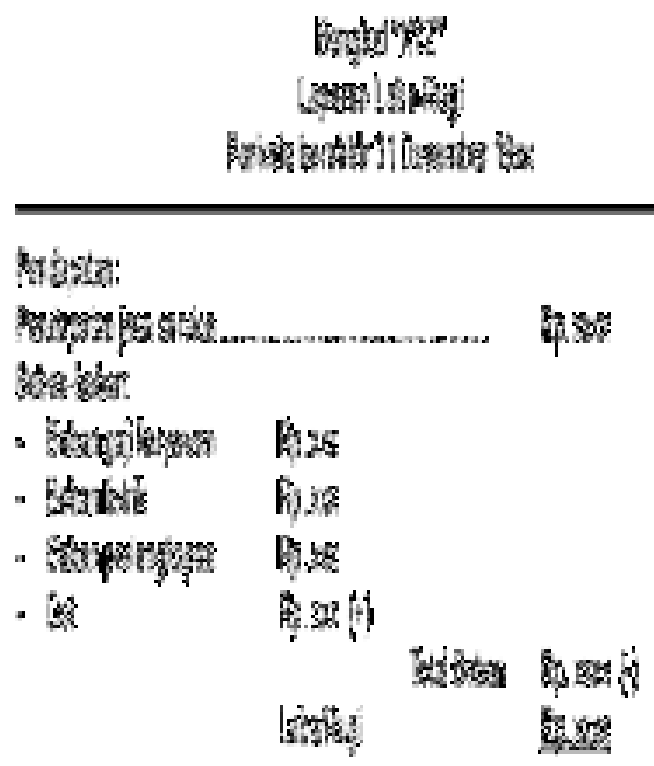

2) Bentuk Majemuk atau Multiple Step merupakan pemisahan antara komponen usaha pokok (operasional) dengan diluar pokok (non operasional). Artinya terlebih dahulu dikurangi antara penghasilan pokok dengan biaya pokok, kemudian baru ditambah dengan hasil pengurangan penghasilan dan biaya diluar pokok. 
Value Jurnal IImiah Akuntansi Keuangan dan Bisnis

Vol. 1 No. 1 Bulan April - September 2020

Contoh Bentuk Laporan Laba Rugi Multiple

Step :

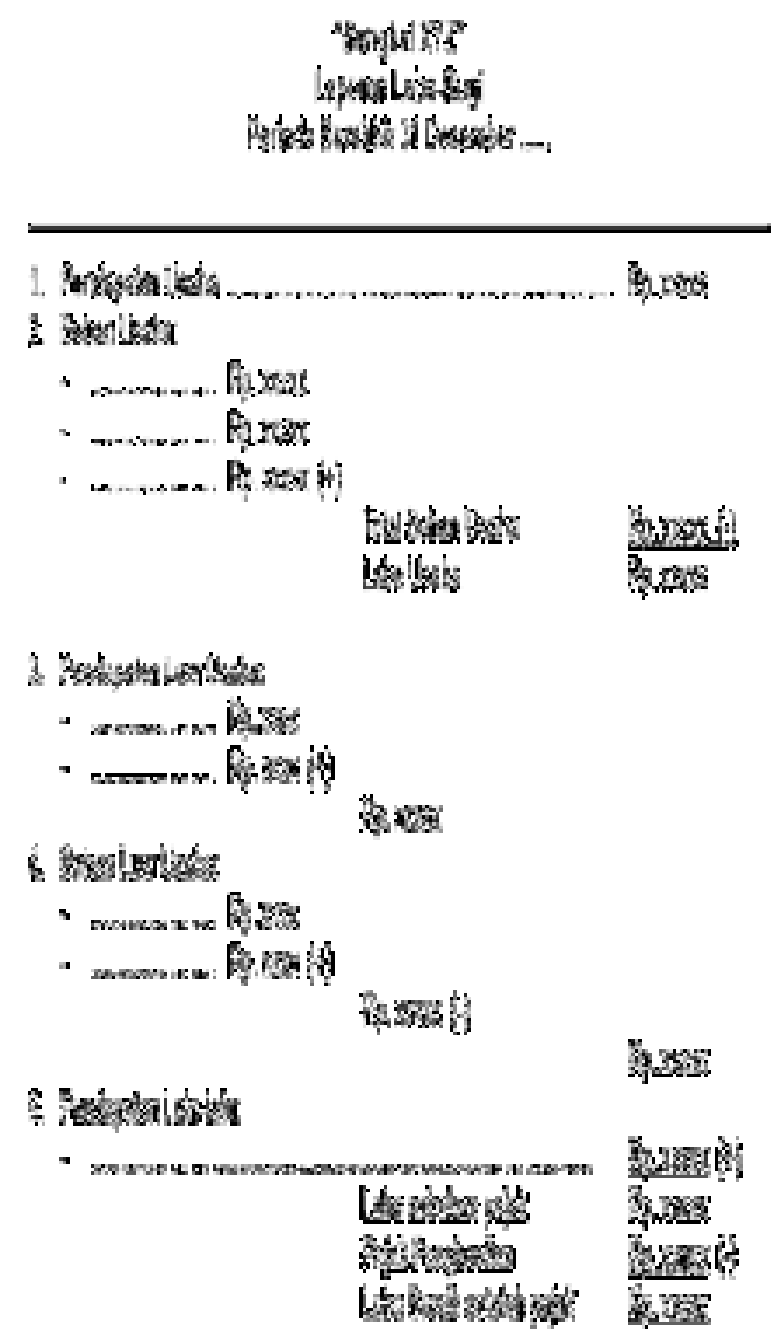

\subsection{Rasio Likuiditas}

\subsubsection{Pengertian Rasio Likuiditas}

Rasio likuiditas merupakan suatu indikator mengenai kemampauan perusahaan membayar semua kewajiban fianansial jangka pendek pada saat jatuh tempo dengan menggunakan aktiva lancar yang tersedia. Likuiditas tidak hanya berkenaan dengan keadaan keseluruhan keuangan perusahaan, tetapi juga berkaitan dengan kemampuannya mengubah aktiva lancar tertentu menjadi kas.

$$
\text { Riyanto (2008:25) “menyatakan }
$$

bahwa likuiditas adalah masalah yang berhubungan dengan masalah kemampuan suatu perusahaan untuk memenuhi kewajiban finansialnya yang segera harus dipenuhi. Suatu perusahaan yang mempunyai alat-alat likuid sedemikian besarnya sehingga mampu memenuhi segala kewajiban financialnya yang segera harus terpenuhi, dikatakan bahwa perusahaan tersebut likuid, dan sebaliknya apabila suatu perusahaan tidak mempunyai alat-alat likuid yang cukup untuk memenuhi segala kewajiban finansialnya yang segera harus terpenuhi dikatakan perusahaan tersebut insolvable.

Rasio likuiditas adalah rasio yang mengukur kemampuan perusahaan memenuhi kewajiban jangka pendeknya. Rasio-rasio ini dapat dihitung melalui sumber informasi tentang modal kerja yaitu pos-pos aktiva lancar dan hutang lancar. Dengan demikian, rasio likuiditas berpengaruh dengan kinerja keuangan perusahaan sehingga rasio ini memiliki hubungan dengan harga saham perusahaan. 
Value Jurnal IImiah Akuntansi Keuangan dan Bisnis

Vol. 1 No. 1 Bulan April - September 2020

\subsubsection{Jenis-Jenis Rasio Likuiditas}

\section{a. Rasio Lancar (current ratio)}

Rasio ini merupakan cara untuk mengukur kesanggupan suatu perusahaan untuk memenuhi kewajiban-kewajibannya, dengan pedoman 2:1 atau 200\% ini adalah rasio minimum yang akan dipertahankan oleh suatu perusahaan. Menurut Fahmi (2011:61), kondisi perusahaan yang memiliki current ratio yang baik adalah dianggap sebagai perusahaan yang baik dan bagus, namun jika current ratio terlalu tinggi juga dianggap tidak baik karena dapat mengindikasikan adanya masalah seperti jumlah persediaan yang relatif tinggi dibandingkan taksiran tingkat penjualan sehingga tingkat perputaran persediaan rendah dan menunjukkan adanya over investment dalam persediaan tersebut atau adanya saldo piutang yang besar yang tak tertagih.

Menurut Fahmi (2011:61) Current ratio dapat dihitung dengan formula:

$$
\text { Current Ratio }=\frac{\text { Aktiva Lancar }}{\text { Utang Lancar }}
$$

Apabila mengukur tingkat likuiditas dengan menggunakan current ratio sebagai alat pengukurnya, maka tingkat likuiditas atau current ratio suatu perusahaan dapat dipertinggi dengan cara (Riyanto, 2010:28) :

1) Dengan utang lancar tertentu, diusahakan untuk menambah aktiva lancar.

2) Dengan aktiva lancar tertentu, diusahakan untuk mengurangi jumlah utang lancar.

3) Dengan mengurangi jumlah utang lancar sama-sama dengan mengurangi aktiva lancar.

Current ratio sangat berguna untuk mengukur likuiditas perusahaan, akan tetapi dapat menjebak. Hal ini dikarenakan current ratio yang tinggi dapat disebabkan adanya piutang yang tidak tertagih yang tentu saja tidak dapat dipakai untuk membayar utang. Untuk menguji apakah alat bayar yang digunakan tersebut likuid, perusahaan harus menentukan alat bayar yang mana yang kurang atau tidak sesuai harus dikeluarkan dari aktiva lancar. Alat bayar yang kurang likuid ini misalnya persediaan dan pos-pos yang analog dengan persediaan.

Jika sebuah perusahaan mengalami kesulitan keuangan, maka perusahaan tersebut mulai membayar tagihannya (utang usaha) dengan lebih lambat, meminjam dari bank, dan lain sebagainya. Jika kewajiban lancar meningkat lebih cepat dibandingkan aktiva lancar, maka rasio lancar akan turun 
Value Jurnal IImiah Akuntansi Keuangan dan Bisnis

Vol. 1 No. 1 Bulan April - September 2020

dan hal ini akan menimbulkan permasalahan. Karena rasio lancar memberikan indikator terbaik atas besarnya klaim kreditor jangka pendek yang dapat ditutup oleh aktiva yang diharapkan akan dikonversi menjadi kas relative lebih cepat, maka hal ini paling banyak digunakan dalam mengukur solvensi jangka pendek.

\section{b. Rasio Cepat (quick ratio)}

Rasio ini disebut juga acid test rasio yang juga digunakan untuk mengukur kemampuan suatu perusahaan dalam memenuhi kewajiban jangka pendeknya. Penghitungan quick ratio dengan mengurangkan aktiva lancar dengan persediaan. Hal ini dikarenakan persediaan merupakan unsur aktiva lancar yang likuiditasnya rendah dan sering mengalami fluktuasi harga serta menimbulkan kerugian jika terjadi likuiditas. Jadi rasio ini merupakan rasio yang menunjukkan kemampuan aktiva lancar yang paling likuid dan mampu menutupi hutang lancar. Menurut Fahmi (2011:62), “apabila menggunakan rasio ini maka dapat dikatakan bahwa jika suatu perusahaan mempunyai nilai quick ratio sebesar kurang dari 100\% atau $1: 1$, hal ini dianggap kurang baik tingkat likuiditasnya".
Menurut Fahmi (2011:62) Quick ratio dapat dihitung dengan formula:

$$
\text { Quick ratio }=\frac{\text { Aktiva Lancar-persediaan }}{\text { Utang lancar }}
$$

Sawir (2009:10) "mengatakan bahwa quick ratio umumnya dianggap baik adalah semakin besar rasio ini maka semakin baik kondisi perusahaan. Ukuran likuiditas perusahaan yang lebih teliti dapat ditemukan pada angka ratio yang disebut rasio cepat (quick ratio). Pada rasio ini persediaan dan persekot biaya dikeluarkan dari total aktiva lancar, dan hanya menyisakan pos-pos aktiva lancar yang likuid saja yang dapat dibagi dengan utang lancar. Rasio cepat dirancang untuk mengukur seberapa baik perusahaan dapat memenuhi kewajibannya, tanpa harus melikuidasi atau bergantung pada persediaannya.

\section{Metode Penelitian}

Teknik analisis yang digunakan adalah metode kuantitatif, yaitu pengolahan data berupa angka-angka dengan menggunakan rasio keuangan. Teknik analisis data yang digunakan penulis diperoleh dari laporan keuangan PT. Angkasa Pura II (Persero) Kualanamo 
Value Jurnal IImiah Akuntansi Keuangan dan Bisnis Vol. 1 No. 1 Bulan April - September 2020

International Airport pada tahun 2017-2018 yang kemudian dianalisis dengan menggunakan dasar-dasar teoritis dari landasan teori yang sudah ada.

\section{Hasil Penelitian dan Pembahasan}

\subsection{Hasil Penelitian}

Analisis Rasio Likuiditas yaitu salah satu alat analisis keuangan yang digunakan perusahaan untuk mengukur keadaan perusahaan dalam memenuhi kewajiban yang akan jatuh tempo atau kewajiban jangka pendek. Di dalam rasio likuiditas terdapat unsur aktiva lancar dan hutang lancar jika aktiva lancar dapat membiayai dengan baik hutang lancar, kondisi likuiditas perusahaan berada pada tingkat aman.

Untuk dapat memenuhi kewajibannya yang sewaktu-waktu ini, maka perusahaan harus mempunyai alat-alat untuk membayar yang berupa aset-aset lancar yang jumlahnya harus jauh lebih besar dari pada kewajiban-kewajiban yang harus segera dibayar berupa kewajibankewajiban lancar.

Berikut ini merupakan hasil dari perhitungan mengenai indikator-indikator yang digunakan untuk menentukan tingkat likuiditas pada PT.Angkasa Pura II (Persero) Kualanamu International Airport Tahun 2017 dan Tahun 2018
Tabel 4.1. Rekapitulasi Data Likuiditas PT. Angkasa Pura II

\begin{tabular}{|c|c|c|}
\hline & $\mathbf{2 0 1 7}$ & $\mathbf{2 0 1 8}$ \\
\hline $\begin{array}{l}\text { Aktiva } \\
\text { lancar }\end{array}$ & 7.355 .423 .998 .612 & 5.507 .894 .339 .826 \\
\hline $\begin{array}{c}\text { Utang } \\
\text { lancar }\end{array}$ & 4.101 .746 .228 .997 & 4.796 .881 .775 .256 \\
\hline Persediaan & 9.814 .414 .171 & 10.613 .246 .110 \\
\hline
\end{tabular}

Sumber: laporan keuangan PT. Angkasa Pura II, diolah oleh peneliti (2020)

\subsection{Pembahasan}

\section{a) Rasio Lancar ( current ratio )}

Current Ratio $=\frac{\text { Aktiva Lancar }}{\text { Utang Lancar }}$

\section{Tahun 2017}

Current Ratio $=\frac{7 \cdot 355 \cdot 423 \cdot 998 \cdot 612}{4.101 .746 .228 .997}=1,79$

$$
\text { 4.101.746.228.997 }
$$

\section{Tahun 2018}

$$
\text { Current Ratio }=\frac{5.507 .894 .339 .826}{4.796 .881 .775 .256}=1,14
$$

Dari hasil perhitungan Rasio Lancar ( current ratio) diatas, maka dapat di simpulkan bahwa di Tahun 2017 Current Rasio adalah sebesar 1,79 berarti setiap Rp. 1,00 hutang untuk tahun 2017 di jamin Rp. 1,79 dan untuk tahun 2018 di dapatkan hasil Current Rasio sebesar 1,14 berarti setiap Rp. 1,00 hutang lancar dijamin sebesar Rp. 1,14. Tahun 2017 dan 2018 terjadi penurunan sebesar 0,65. Berarti Rasio Lancar Tahun 2017 lebih baik dibandingkan Tahun 2018. 
Value Jurnal IImiah Akuntansi Keuangan dan Bisnis

Vol. 1 No. 1 Bulan April - September 2020

Jika rata-rata industri untuk current ratio adalah 2,00, maka keadaan perusahaan ini untuk tahun 2017 dan tahun 2018 kondisinya kurang baik karena rasionya masih dibawah rata-rata industri.

\section{b) Rasio Cepat ( quick ratio )}

Quick Ratio $=\frac{\text { Aktiva Lancar - Persediaan }}{\text { Utang Lancar }}$

Tahun 2017

Quick Ratio

$$
=\frac{7.355 .423 .998 .612-9.814 .414 .171}{4.101 .746 .228 .997}=1,79
$$

\section{Tahun 2018}

Quick Ratio

$=5.507 .894 .339 .826-10.613 .246 .110$

4.796.881.775.256

$=1,15$

Dari hasil perhitungan Rasio Cepat (Quick ratio) diatas, maka dapat di simpulkan bahwa di Tahun 2017 Quick Rasio adalah sebesar 1,79 berarti setiap Rp. 1,00 hutang lancar di tahun 2017 dijamin sebesar Rp. 1,79 dan untuk tahun 2018 di dapatkan hasil Quick Rasio sebesar 1,15 berarti setiap Rp. 1,00 hutang lancar dijamin sebesar Rp. 1,15. Tahun 2017 dan 2018 terjadi penurunan sebesar 0,64. Berarti Rasio Cepat Tahun 2017 lebih baik dibandingkan Tahun 2018. Jika rata-rata industri untuk quick ratio adalah 1,00, maka keadaan perusahaan ini untuk tahun 2017 dan tahun 2018 kondisinya baik karena rasionya diatas ratarata industri.

\section{Kesimpulan dan Saran}

\subsection{Kesimpulan:}

Tingkat rasio likuiditas pada Perusahaan ini Secara umum telah memenuhi standar rasio yang ditetapkan. Meskipun terdapat penurunan, penurunan tersebut tidak terlalu rendah dan masih dalam keadaan sesuai dengan standar rasio maupun standar industri. Dalam hal tersebut keadaan keuangan pada perusahaan ini masih dalam keaadaan liquid terlihat dari perbandingan antara aktiva lancar lebih besar dari pada hutang lancar.

\subsection{Saran}

PT. Angkasa Pura II (Persero) diharapkan mampu menangani aktivitas diluar operasi dengan lebih baik lagi sehingga kas yang dihasilkan tidak menurun dan lebih baik

\section{DAFTAR PUSTAKA}


Admaja, Lukas. 2010. Manajemen Keuangan. Website: $\mathrm{http} /$ Artikel.Manajemen. keuangan.com.

AL Haryono, Jusup. 2009. Akuntansi. Edisi Terbaru. Jilid 3. Yogyakarta: STIE YKPN.

Amir Abadi Jusuf. 2009. Pengantar Akuntansi. Jilid 1. Jakarta: Salemba Empat.

Drs. Jumingan, S.E.,M.M.,M.Si. Analisis Laporan Keuangan edisi keempat. Penerbit Bumi Aksara tahun 2011.

J. Fred Weston, Eugene Dasar-Dasar Manajemen Keuangan edisi ketujuh. Penerbit Erlangga tahun 2004.

James O. Giel Dasar-Dasar Analisis Keuangan. Informasi Keuangan
Untuk Semua Manajer. Penerbit PPM 2004.

Mamduh M. Hanafi dan Abdul Halim. 2009. Analisis Laporan Keuangan.

Riyanto, Bambang. 2008. Dasar-dasar Pembelajaran Perusahaan. Yogyakarta: BPFE.

Samuel. Likuiditas, Ask A Question. Website: http://www.e-samuel.com. Diakses bulan Februari 2007.

Sawir, Agnes. 2009. Analisa Kinerja Keuangan dan Perencanaan Keuangan Perusahaan. Jakarta: PT. Gramedia Pustaka Utama.

Sofyan Syafri Harahap, 2009. Analisa Kritis Atas Laporan Keuangan. 